Article

\title{
Pantoea spp. Associated with Smooth Crabgrass (Digitaria ischaemum) Seed Inhibit Competitor Plant Species
}

\author{
Matthew T. Elmore ${ }^{1, * \mathbb{D}}$, James F. White ${ }^{1}{ }^{\mathbb{D}}$, Kathryn L. Kingsley ${ }^{1}$, Katherine H. Diehl ${ }^{1}$ and \\ Satish K. Verma ${ }^{2}$ \\ 1 Department of Plant Biology, Rutgers University, 59 Dudley Rd., New Brunswick, NJ 08901, USA; \\ jwhite3728@gmail.com (J.F.W.); kathryn.l.kingsley@gmail.com (K.L.K.); \\ katherine.diehl@rutgers.edu (K.H.D.) \\ 2 Centre of Advanced Study in Botany, Banaras Hindu University, Varanasi 211005, India; \\ skvermabhu@gmail.com \\ * Correspondence: matthew.elmore@rutgers.edu
}

Received: 11 April 2019; Accepted: 17 May 2019; Published: 21 May 2019

\begin{abstract}
Digitaria ischaemum (Schreb.) Schreb. ex Muhl. and Poa annua L. are competitive, early successional species which are usually considered weeds in agricultural and turfgrass systems. Bacteria and fungi associated with D. ischaemum and P. annua seed may contribute to their competitiveness by antagonizing competitor forbs, and were studied in axenic culture. Pantoea spp. were the most common bacterial isolate of $D$. ischaemum seed, while Epicoccum and Curvularia spp. were common fungal isolates. A variety of species were collected from non-surface sterilized P. annua. Certain Pantoea spp. isolates were antagonistic to competitor forbs Taraxacum officinale, Trifolium repens. All bacterial isolates that affected $T$. officinale mortality were isolated from $D$. ischaemum seed while none of the P. annua isolates affected mortality. Two selected bacterial isolates identified as Pantoea ananatis were evaluated further on D. ischaemum, T. repens (a competitor forb) and P. annua (a competitor grass) alone and in combination with a Curvularia sp. fungus. These bacteria alone caused $>65 \%$ T. repens seedling mortality but did not affect $P$. annua seedling mortality. These experiments demonstrate that Pantoea ananatis associated with $D$. ischaemum seeds is antagonistic to competitor forbs in axenic culture. The weedy character of D. ischaemum could at least in part stem from the possession of bacteria that are antagonistic to competitor species.
\end{abstract}

Keywords: biological control; bioherbicide; Curvularia; Pantoea; Pantoea ananatis; weed ecology

\section{Introduction}

Digitaria (crabgrass) species are some of the most competitive $\mathrm{C}_{4}$ weeds of agricultural, horticultural and turfgrass landscapes in tropical and temperate regions. Digitaria ischaemum and D. sanguinalis (smooth and large crabgrass, respectively) are among most problematic weed species in the United States, and are particularly well adapted to turfgrass systems where as a $C_{4}$ species they often outcompete $C_{3}$ grasses and forbs in the summertime [1]. Digitaria sanguinalis is known to produce allelochemicals that may contribute to its competitiveness, but these have not been studied extensively [2,3].

Poa annua is another prolific early successional $C_{3}$ plant that is extremely competitive in turfgrass and horticultural systems and can be found on all seven continents [4]. The success of P. annua as a weed is attributed to genotypic variability, prolific seed production, and a short life cycle [5].

The weed microbiome may also contribute to weed competitiveness. Communities of bacteria and fungi which colonize internal tissues as commensals or mutualists are referred to as endophytes and are ubiquitous in plants (reviewed in [6-8]). A wide range of endophytes are commonly found in 
plants, although there are several potential mechanisms that reduce microbial endophyte density and diversity when compared with the root rhizosphere [6,9]. These endophytes can affect tolerance to abiotic and biotic stressors such as disease, drought, heat and salinity [10,11].

The well-studied Epichloë endophyte symbionts are known to confer enhanced drought tolerance and resistance to insect herbivory in grasses $[12,13]$. These fungi are vertically transmitted through seed of the host plant. It is thought that early-successional weeds may rely on associations with non-clavicipitaceous endophytes to increase their competitiveness, although these have not been studied extensively [14]. Two exceptions are endophytes associated with Centaurea stoebe and Phragmites australis, which can be invasive outside of their native range. A sampling of fungal endophytes associated with $C$. stoebe achenes (seeds) in the invaded range (North America) found that they were more diverse and were taxonomically different than those associated with plants in the native (European) range [15]. Other researchers found C. stoebe infected with a fungal endophyte from the native range and another endophyte common to the non-native range suppressed competitor grasses of the invaded range more than grasses in the native range [16]. There is considerable diversity among fungal endophytes of $P$. australis in North America as well, although the contribution of these endophytes to fitness of mature plants is unknown [17]. However, other researchers have demonstrated that $P$. australis seed-associated bacteria and fungi from native and invaded ranges can enhance germination, seedling growth and antagonize other species [18-20].

Although Digitaria ischaemum and Poa annua are not classified as invasive weeds like P. australis and C. stoebe, they are very prolific in North America outside of their native Eurasian range [1,21]. It is not known whether endophytes affect competitiveness of Digitaria spp. or P. annua. Endophytes of $P$. annua have not been reported, but this weed has been found to cause changes in the soil microbial community that affect the fitness of mid-successional species [22]. Previous research has examined fungal endophytes of Digitaria spp., but not seed-associated bacteria, and. found over 20 different fungal taxa endophytic to roots of D. ischaemum grown in a geothermal soil in China [23]. They found most of these endophytic fungi of $D$. ischaemum were also found in the rhizospheric soil, but there were some species found only in the plant, including Curvularia protuberata, suggesting endophytes were vertically or horizontally transmitted. Other researchers have demonstrated that C. protuberata colonized by a virus increases thermotolerance of Dichanthelium lanuginosum (panic grass) [24-26]. This previous research with Digitaria spp. endophytes did not examine their role in antagonizing competitor plants.

Compared to endophytes of root and shoot tissues, considerably less research has been conducted on seed-associated bacteria. Prolific seed production is a key strategy for P. annua and D. ischaemum survival. Where P. annua populations are high, seedbank densities have been reported at between 20,000 and 200,000 seeds per $\mathrm{m}^{2}$ [27]. D. ischaemum and D. sanguinalis are annuals that survive by prolific seed production and can produce up to 188,000 seeds per plant [1]. Bacterial endophytes have been isolated from seed of several food crop species including rice (Oryza sativa), maize (Zea mays) as well as certain grass species $[7,28,29]$. These endophytes can be important for seedling growth and development and can contribute to the endophytic community of a mature plant [30,31]. In forbs, fungal endophytes can be vertically transmitted from seed to true leaves in aseptic conditions after surface-sterilization [32]. In grasses, bacterial endophytes can be transmitted from mature maize parents to seed offspring [33]. It is possible that these endophytes are vertically transmitted because they benefit the host plant. Cultivable diazotrophic endophytes of Pennisetum purpureum, a perennial $\mathrm{C}_{4}$ plant that is capable of producing large amounts of biomass under low or high $\mathrm{N}_{2}$ fertilization were found to produce indole acetic acid and solubilize phosphate and may play a role in the competitiveness of this $\mathrm{C}_{4}$ grass in the wild [34].

We hypothesized that bacteria and fungi associated with D. ischaemum and P. annua seed antagonize competitor species and enhance the ability of host seedlings to grow. Therefore, the objectives of our research were to: (1) Identify seed-vectored bacteria and fungi, and (2) Determine the effect of these bacteria and fungi on competitor forbs as well as host species. 


\section{Materials and Methods}

\subsection{Seed Collection}

Digitaria ischaemum seed was collected from a single site at the Rutgers Horticultural Research Farm No. 2 in North Brunswick, NJ (40 $45^{\prime} 25^{\prime \prime}$ N 74 $\left.47^{\prime} 67^{\prime \prime} \mathrm{W}\right)$. The site consisted of a mixed stand of $D$. ischaemum and Lolium perenne maintained as a mowed stand of turfgrass for several years. Mowing was suspended in October to allow inflorescence production and maturity prior to harvest in November 2016. Seed was collected from a $300 \mathrm{~m}^{2}$ area using a leaf sweeper. Seeds were stored at $13{ }^{\circ} \mathrm{C}$ until January 2017 where they were moved to storage at $-20{ }^{\circ} \mathrm{C}$ for one week prior to preparation to break seed dormancy. Poa annua seed was collected in June 2016 from a single site in University Park, PA $\left(40^{\circ} 81^{\prime} 09^{\prime \prime} \mathrm{N} 77^{\circ} 86^{\prime} 73^{\prime \prime} \mathrm{W}\right)$ that was maintained as a mowed turfgrass stand for several years. Seeds were stored at $13{ }^{\circ} \mathrm{C}$ until January 2017 where they were moved to storage at $-20{ }^{\circ} \mathrm{C}$ for one week prior to preparation to break seed dormancy.

\subsection{Surface Sterilization and Microbe Isolation}

P. annua and D. ischaemum seeds were surface sterilized by placing $5 \mathrm{~g}$ of seed in a $200 \mathrm{~mL}$ container filled with a $160 \mathrm{~mL}$ solution of DI water and $4.125 \%(v / v) \mathrm{NaOCl}$ based on the methods of [20]. This container was placed on an orbital shaker to vigorously agitate the solution for $40 \mathrm{~min}$. The bleach solution was then decanted and seeds were rinsed at least five times with sterile DI water in a laminar flow hood. Seeds were then placed on Petri dishes containing yeast extract sucrose agar (YESA; 1\% yeast extract, 1\% sucrose, 1.2\% agar) and the plates were incubated at room temperature. Four seeds were placed on each plate and there were 10 replicates. The process was repeated with $D$. ischaemum seed one week later with 8 replicates; a second $5 \mathrm{~g}$ sample of seed was sterilized using the same process except that $5 \mu \mathrm{L}$ of polysorbate 20 (Tween20, Thermo Fisher Scientific, Waltham, MA, USA) was added to the $160 \mathrm{~mL}$ of $4.125 \%(v / v) \mathrm{NaOCl}$ solution. Outgrowing fungi were observed after $48 \mathrm{~h}$ of incubation and isolated to pure culture on potato dextrose agar for further study. After 7 to 14 days of incubation, bacteria were observed and isolated to pure culture on Luria-Bertani (LB) agar for further study. No outgrowing fungi or bacteria were observed in surface-sterilized P. annua seed after 14 days of observation. Therefore, using the same methods described above except without $\mathrm{NaOCl}$, $P$. annua seeds were agitated in sterile water for $5 \mathrm{~min}$ and then the water was decanted and seeds were rinsed with sterile water before placing on YESA to isolate bacteria from non-surface-sterilized seeds.

\subsection{Bacterial Identification and Characterization}

Genomic DNA from bacteria was isolated using GenElute Bacterial Genomic DNA Kits (SigmaAldrich, St. Louis, MO, USA). Bacterial identifications were made by obtaining $16 \mathrm{~S}$ rDNAsequences after methods employed by [35] using universal primers 16SF (5'-AGAGTTTGATCCTGGCTCAG-3') and 16SR (5'-CTACGGCTACCTTGTTACGA-3'). Amplified PCR products were resolved by electrophoresis in $1.5 \%(w / v)$ agarose gel stained with SYBR safe for visual examination. The PCR products were purified using a PCR purification kit (Qiagen, Germantown, MD, USA) and sent to Genewiz Inc. (South Plainfield, NJ, USA) for sequencing. For certain isolates determined to be of interest after initial experiments (Pantoea spp. isolates 4 and 5), the tuf gene was also sequenced. Amplification of rDNA was performed in a $25 \mu \mathrm{L}$ volume comprising: $12.5 \mu \mathrm{L}$ Taq NEB 2x Master Mix, $9.5 \mu \mathrm{L}$ water, $1.0 \mu \mathrm{L}$ forward tufGPR (5'-GATACCAGTTACGTCAGTTGTACGGA-3'), $1.0 \mu \mathrm{L}$ reverse tufGPF (5'-ACGTTGACTGCCCAGGACAC-3') and $1.0 \mu \mathrm{L}$ DNA. The reaction was performed in a thermocycler with an initial denaturation at $95{ }^{\circ} \mathrm{C}$ for $3 \mathrm{~min}$, followed by 35 cycles at $95{ }^{\circ} \mathrm{C}$ for $30 \mathrm{~s}, 55{ }^{\circ} \mathrm{C}$ for $1 \mathrm{~min}, 72{ }^{\circ} \mathrm{C}$ for $30 \mathrm{~s}$, and a final extension at $72{ }^{\circ} \mathrm{C}$ for $5 \mathrm{~min}$. Sequences were compared to GenBank accessions using BLASTn (Available online: http://www.ncbi.nlm.nih.gov). Sequences were deposited in GenBank under accession numbers MG100861 to 863 and MK733357 to 370. 


\subsection{Experiment 1: Effect of Bacterial Isolates on Taraxacum Officinale Seedling Mortality}

In turfgrass systems, Taraxacum officinale is a common competitor forb and was selected for use in these experiments. T. officinale seeds (collected from a lawn in South River, NJ, USA) were surface sterilized using the same process described above for D. ischaemum surface sterilization (agitation with $4.125 \% \mathrm{NaOCl}$ for $40 \mathrm{~min}$ ). Ten T. officinale seeds were plated onto each experimental unit, which consisted of a Petri dish ( $85 \mathrm{~mm}$ diameter) filled with $0.7 \%$ agarose media with no mineral nutrients. Petri dishes were maintained at ambient room temperature $\left(22^{\circ} \mathrm{C}\right.$ to $\left.27^{\circ} \mathrm{C}\right) 40 \mathrm{~cm}$ below a fluorescent light source emitting $65 \mu \mathrm{mol} \mathrm{m}{ }^{-2} \mathrm{~s}^{-1}$ PAR for $16 \mathrm{~h}$ per day. Isolates were maintained on trypticase soy agar (TSA) and streaked onto LB agar 12 to $24 \mathrm{~h}$ before inoculation. The bacteria were then removed from the agar with an inoculation loop and suspended in $1 \mathrm{~mL}$ of sterile water. Using this method, the suspension typically measured $0.8 \mathrm{OD} \pm 0.1(600 \mathrm{~nm})$ when diluted 1:3 with sterile water. One $3 \mu \mathrm{L}$ drop of bacterial suspension was pipetted onto each seed within $1 \mathrm{~h}$ of placement on agarose. Isolates listed in Table 1 was evaluated in triplicate on a total of 30 seeds. A non-treated axenic control was included for comparison. A Pseudomonas fluorescens (Sandy LB4; GenBank No. KX665565) and Pantoea sp. isolate (RiLB4; GenBank No. KX752781) isolated from Phragmites australis seed by [20] were included as standards of comparison. The Sandy LB4 isolate has been shown to increase mortality of competitor forbs including T. officinale while RiLB4 did not affect mortality.

T. officinale seedlings that germinated (radicle at least $1 \mathrm{~mm}$ in length) were assessed as healthy, injured or dead at 14 days after treatment. Seedlings were considered healthy if cotyledons and leaves were green in color, turgid and not displaying any symptoms of cell membrane leakage (necrosis or greasy, off-color leaf tissues). Seedlings were considered dead if they were completely necrotic. Seedlings were scored as injured if they displayed some injury symptoms (i.e., chlorosis, necrosis) but other sections of the seedling were healthy and the seedling was not completely dead. The number of healthy, injured, and dead seedlings was assessed in each Petri dish and this number was used to determine the percentage of healthy, injured or dead plants in each experimental unit. Isolates were inoculated on different dates. Therefore, separate non-treated axenic controls were used for each experimental run and comparisons were made only to the non-treated control within each experiment. For isolates that increased mortality compared to the non-treated control, this experiment was repeated on T. officinale and T. repens. T. repens is also a common competitor species in turfgrass. T. repens seeds (purchased from a commercial seed source) were surface-sterilized using a similar method as T. officinale except that a $2 \%(v / v) \mathrm{NaOCl}$ solution was used instead of a $4.125 \%$ solution. To ensure this method effectively sterilized clover seed, 100 seeds were placed on LB agar and no bacteria or fungi were observed after $10 \mathrm{~d}$ of incubation.

After T. officinale plants were evaluated at 14 days after treatments, the agarose plates containing seedlings were flooded with a $2 \mathrm{mmol} / \mathrm{L}$ solution of 3,3-diaminobenzidine tetrahydrochloride dissolved in DI water (DAB; Sigma Aldrich, St. Louis, MO) $12 \mathrm{~h}$ prior to observation to aid in visual observation of bacteria [36]. Randomly selected inoculated and non-inoculated plants were removed from the agarose and squash prepared with aniline blue $(0.01 \%)$ dissolved in water and lactic acid for microscope observation at $1000 \times$ magnification.

\subsection{Experiment 2: Effect of Bacterial Isolates on D. ischaemum Germination and Seedling Mortality}

Based on the results of Experiment 1, Pantoea spp. bacterial isolates $(4,5,8,18$, and 22) were evaluated against peeled, surface-sterilized $D$. ischaemum seedlings. To successfully remove cultivable bacteria from $D$. ischaemum seeds required several iterations of various sterilization procedures before an effective method was found. Seeds were placed on mesh screen and a wooden block was used to rub the seeds through the plastic screen, which removed the paleas and lemmas. These seeds were then placed on a finer plastic screen and a wooden block wrapped in the same screen was rubbed on the seed to remove the seed coat. These peeled seeds were separated from the debris and put into a $2 \mathrm{~mL}$ microcentrifuge tube filled with $1.5 \mathrm{~mL}$ of a $1.5 \%(v / v) \mathrm{NaOCl}$ solution. The tube was vortexed for $5 \mathrm{~min}$, the $\mathrm{NaOCl}$ solution was removed and fresh solution was added before vortexing again for $5 \mathrm{~min}$. 
Seeds were then rinsed several times with sterile water. To ensure this method effectively sterilized D. ischaemum seed, 100 seeds were placed on LB agar. No bacteria were observed after 10 days of incubation and a Curvularia sp. (determined through morphological characterization) was observed outgrowing from $2 / 100$ seeds.

Surface-sterilized, peeled, $D$. ischaemum seeds were placed on agarose and inoculated with bacteria in the same manner as described in Experiment 1. T. officinale seeds were prepared using the same methods as in Experiment 1 included in the experiment as a standard of comparison to Experiment 1. This experiment was conducted once, but was repeated with Isolates 4 and 5 within Experiment 3.

2.6. Experiment 3: Effect of Bacterial Isolates Alone and in Combination with Curvularia sp. on D. ischaemum, T. repens and P. annua Seedlings

The objective of these experiments was to evaluate the effect of certain bacterial isolates alone and in combination with a Curvularia sp. on germination and mortality of D. ischaemum, P. annua and T. repens. This experiment was conducted twice on separate dates. P. annua selected as it is a $\mathrm{C}_{3}$ grass and also as a model plant that can be used evaluate the effect of these treatments on root gravitropism and root length based on previous research $[20,37]$.

Surface-sterilized D. ischaemum, T. repens, and P. annua seeds were placed on agarose and inoculated as described previously. Peeled $D$. ischaemum seeds were used in this experiment. Seeds were inoculated with bacterial isolates 4 and 5, the combination of $4+5$, RiLB4 (standard), or no bacteria alone and in combination with a Curvularia sp. isolate collected outgrowing from D. ischaemum seed forming a factorial treatment design. Bacterial isolates were prepared and inoculated onto seeds in the same manner as described for Experiment 1; isolates 4 and 5 were combined by taking an aliquot of each bacterial suspension and combining them in a 1:1 ratio. A suspension of Curvularia conidia was prepared by gently washing a potato dextrose agar lawn culture with a solution of sterile water and $0.05 \%$ polysorbate 20 and lightly scraping with an inoculation loop. This resulted in a suspension that contained some hyphae but was primarily conidia. Four $10 \mu \mathrm{L}$ aliquots were sampled and evaluated with a hemocytometer grid to determine the conidia concentration. Within $2 \mathrm{~h}$ of spore suspension preparation, a 2 or $4 \mu \mathrm{L}$ drop (run A and B, respectively) was applied to each seed to inoculate $10^{3} \pm 200$ conidia per seed. The effect of each treatment on germination and seedling mortality was evaluated as previously described in Experiment 1.

For each P. апnua seedling, it was determined whether the root penetrated vertically into the agarose or grew horizontally along the surface of the agarose at 14 days after inoculation. Roots penetrating the agarose were determined to have a positive gravitropic response and the percentage of roots demonstrating a positive gravitropic response is presented [38]. P. annua root length was measured by removing the plant from the agarose and measuring the length of the primary root with a ruler.

\subsection{Statistical Analysis}

Experimental units were arranged in a completely randomized design in all experiments. For Experiments 1 and 2, a single-factor ANOVA was conducted using the GLM procedure in SAS (SAS Institute, Cary, NC, USA) v9.4 $(\alpha=0.05)$. For Experiment 3 , treatments were subjected to a factorial analysis with bacteria isolate and Curvularia inoculation serving as main effects. Means were separated using Fisher's Protected LSD test at the 0.05 level.

\section{Results}

\subsection{Bacterial and Fungal Isolates}

All isolates identified to the genus level had 16S rRNA sequences with $>99 \%$ similarity to known sequences except for two (isolates 22 and 23) that had 94 and $95 \%$ similarity (Table 1). Pantoea, Staphylococcus and Paenibacillus spp. were isolated from non-surface sterilized P. annua seed. 
No bacteria or fungi were observed outgrowing from surface sterilized P. annua seed. A Xanthomonas and Methylobacterium sp. along with eleven Pantoea spp. were selected from surface sterilized D. ischaemum seeds. Two Pantoea isolates of interest (4 and 5) were identified as Pantoea ananatis based on both $16 \mathrm{~S}$ sequence similarity to Pantoea spp. and tuf gene sequences with $>99 \%$ similarity to Pantoea ananatis. Two unique fungal species were isolated and determined to be Epicoccum and Curvularia spp. through morphological characterization [37]. A Curvularia sp. was observed on 55\% and $28 \%$ of the seeds in the first and second experimental run, respectively, and was isolated for further experimentation given its prevalence on surface-sterilized seed in this experiment and previous reports of Curvularia sp. affecting thermotolerance [24-26]. An Epicoccum sp. was observed outgrowing from 4 of 40 seeds in the first run and 10 out of 32 seeds in the second run.

Table 1. Effect of bacteria collected outgrowing from surface-sterilized Digitaria ischaemum seeds and non-surface-sterilize Poа апnиа on Taraxacum officinale seedling mortality in axenic agarose culture 14 days after inoculation. Isolates 1 to 6,7 to 12,13 to 18 , and 19 to 24 were evaluated in separate experiments in Run A. A non-treated control was included in each experiment. Sandy LB4 and RiLB4 (Genbank No. KX752781 and KX665565, respectively) were included as standards and evaluated with isolates 7 to 12 .

\begin{tabular}{|c|c|c|c|}
\hline Isolate No. & Isolated from & Seedling Mortality (\%) ${ }^{\dagger}$ & Seedlings Injured (\%) \\
\hline 1 & P. annua & 0 & 21 \\
\hline 2 & P. annua & 0 & 5 \\
\hline 3 & P. апnиа & 0 & 7 \\
\hline 4 & D. ischaemum & $19 *, \S$ & $44^{*}$ \\
\hline 5 & D. ischaemum & $47^{*}$ & 87 * \\
\hline 6 & P. аппиа & 0 & 6 \\
\hline No bacteria & - & 0 & 18 \\
\hline 7 & P. аппиа & 0 & 11 \\
\hline 8 & D. ischaemum & 29 & $69 *$ \\
\hline 9 & D. ischaemum & 13 & $42 *$ \\
\hline 10 & D. ischaemum & 8 & $67 *$ \\
\hline 11 & P. annua & 0 & $30 *$ \\
\hline 12 & D. ischaemum & 10 & $67 *$ \\
\hline No bacteria & - & 0 & 3 \\
\hline 13 & D. ischaemum & 21 & 54 \\
\hline 14 & P. апnиа & 0 & 31 \\
\hline 15 & P. аппиа & 0 & 16 \\
\hline 16 & D. ischaemum & 10 & 27 \\
\hline 17 & D. ischaemum & 14 & 52 \\
\hline 18 & D. ischaemum & 23 & 40 \\
\hline No bacteria & - & 0 & 22 \\
\hline 19 & P. аппиа & 0 & 45 \\
\hline 20 & D. ischaemum & 0 & 41 \\
\hline 21 & D. ischaemum & $39 *$ & $80 *$ \\
\hline 22 & D. ischaemum & $37 *$ & $79 *$ \\
\hline 23 & D. ischaemum & 0 & 36 \\
\hline 24 & D. ischaemum & 0 & $46^{*}$ \\
\hline RiLB4 & P. australis & 0 & 11 \\
\hline Sandy LB4 & P. australis & 8 & 35 \\
\hline No bacteria & - & 0 & 38 \\
\hline
\end{tabular}

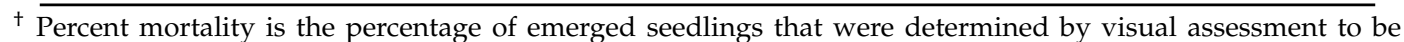
completely dead. Seedlings were scored as injured if they displayed some injury symptoms but were not completely dead. $\$$ An asterisk indicates that the level of mortality or injury was significantly different from the non-treated control according to Fisher's Protected LSD test $(\alpha=0.05)$. Isolates were evaluated in four separate experiments.

\subsection{Experiment 1: Effect of Bacterial Isolates on Taraxacum Officinale Seedling Mortality}

None of the bacteria isolated from P. annua seed caused T. officinale seedling mortality (Table 1). A Staphylococcus sp. isolate from P. annua caused minor T. officinale seedling injury. This experiment 
indicates that bacteria isolated from non-surface-sterilized $P$. annua seed are not pathogenic to T. officinale seedlings.

While bacteria isolated from P. annua had limited or no effects on T. officinale, the most notable isolates from $D$. ischaemum $(4,5,21$, and 22) were Pantoea spp. that caused seedling mortality. Other isolates from $D$. ischaemum $(8,9,10,12,21,22$, and 24) were not as antagonistic to T. officinale but still caused seedling injury and these were also Pantoea spp. while one isolate (18) was a Xanthomonas sp. These Pantoea spp. and Xanthomonas sp. were selected for futher study.

When these isolates were evaluated in a second experiment, isolates 5 and 8 caused the greatest T. officinale seedling mortality (Table 2). These isolates also caused injury to T. repens seedlings at 7 days after inoculation, and these seedlings likely would have completely died if observed 14 days after inoculation, as mortality of inoculated seedlings increased between 7 and 14 days after inoculation in subsequent experiments (reported herein). In previous research evaluating bacteria isolated from Phragmites australis, [20] demonstrated that Pseudomonas fluorescens strain Sandy LB4 caused $>70 \%$ T. officinale seedling mortality while a Pantoea sp. strain RiLB4 did not increase mortality compared to the axenic control. In our experiments, Sandy LB4 nor RiLB4 increased T. officinale mortality compared to the bacteria free control.

Bacteria were observed in squash preparations of T. officinale root tips treated with isolates 4 and 5 . Root hairs of seedlings treated with isolates 4 and 5 were malformed and the membrane at the tip of the root hair was often completely destroyed where bacteria were present (Figure 1). Intact root hairs were observed in the axenic controls. Based on the results of this experiment, we selected isolates 4, 5, 8,18 , and 22 for further study.

Table 2. Effect of bacteria collected outgrowing from surface-sterilized Digitaria ischaemum seeds on Taraxacum officinale seedling mortality 14 days after inoculation and Trifolium repens 7 days after inoculation in axenic agarose culture. Only certain isolates were evaluated based on the results of Run A. Isolates RiLB4 and Sandy LB4 (Genbank No. KX752781 and KX665565, respectively) were isolated from Phragmites australis and were included as standards.

\begin{tabular}{ccccc}
\hline & \multicolumn{2}{c}{ T. officinale } & \multicolumn{2}{c}{ T. repens } \\
\hline Isolate No. & $\begin{array}{c}\text { Seedling Mortality } \\
(\mathbf{\%})^{+}\end{array}$ & $\begin{array}{c}\text { Seedlings Injured } \\
(\%)\end{array}$ & $\begin{array}{c}\text { Seedling Mortality } \\
(\%)\end{array}$ & $\begin{array}{c}\text { Seedlings Injured } \\
(\%)\end{array}$ \\
\hline 4 & 12 & $49^{*}$ & $16^{*}$ & $88^{*}$ \\
5 & $39^{*, \S}$ & $68^{*}$ & 5 & $76^{*}$ \\
8 & $17^{*}$ & $42^{*}$ & 8 & $83^{*}$ \\
10 & 3 & 19 & 8 & $84^{*}$ \\
12 & 11 & $33^{*}$ & 12 & $93^{*}$ \\
13 & 11 & 22 & 8 & $78^{*}$ \\
17 & 4 & $40^{*}$ & 7 & $67^{*}$ \\
18 & 0 & $29^{*}$ & $49 *$ & $84^{*}$ \\
21 & 4 & 17 & 7 & $89^{*}$ \\
22 & 4 & $40^{*}$ & 0 & $96^{*}$ \\
RiLB4 & - & - & 0 & 36 \\
Sandy LB4 & 0 & 42 & 0 & 23 \\
None & 0 & 0 & 34 \\
\hline
\end{tabular}

${ }^{\dagger}$ Percent mortality is the percentage of emerged seedlings that were determined by visual assessment to be completely dead. Seedlings were scored as injured if they displayed some injury symptoms but were not completely dead. ${ }^{\S}$ An asterisk indicates that this level of mortality was significantly different from the non-treated control according to Fisher's Protected LSD test $(\alpha=0.05)$. 


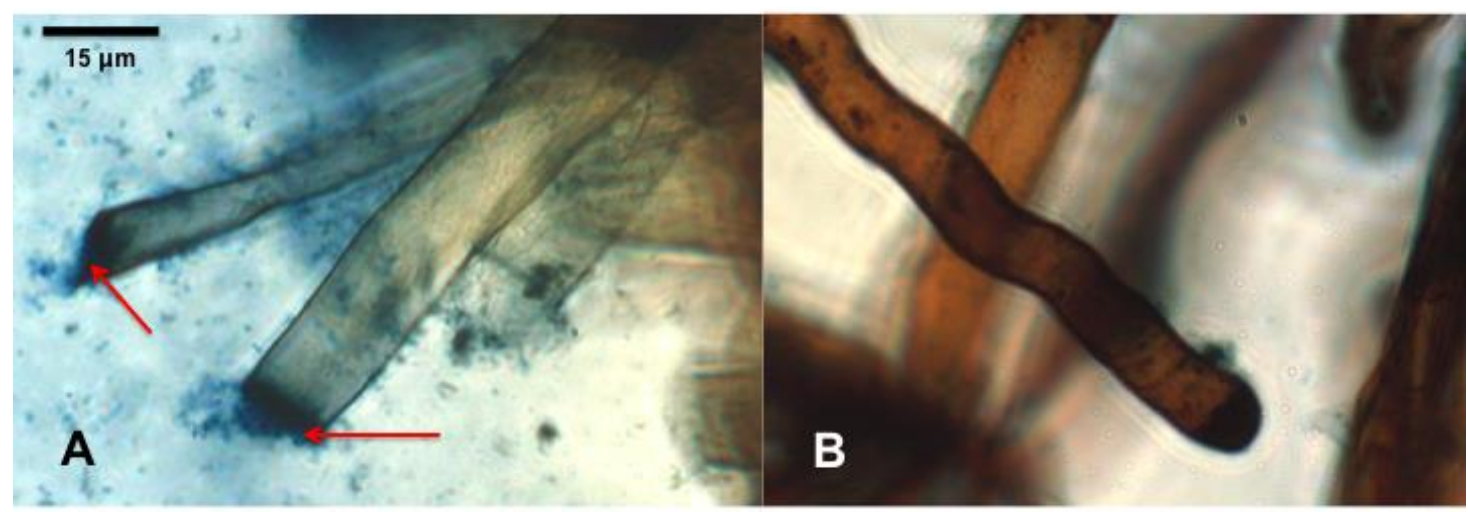

Figure 1. Taraxacum officinale seedling root hairs stained with aniline blue and DAB to visualize reactive oxygen species $\left(\mathrm{H}_{2} \mathrm{O}_{2} 14\right.$ days after seeds were inoculated with a Pantoea sp. (Isolate 4). Root hairs of an inoculated seedling (A) have ruptured while root hairs from a non-inoculated seed (B) are intact (indicated with arrows).

\subsection{Experiment 2: Effect of Bacterial Isolates on D. ischaemum Germination and Seedling Mortality}

Isolate 22 and the combination of isolates 4 and 5 reduced $D$. ischaemum germination from $57 \%$ in the control to $33 \%$ and $20 \%$, respectively (Table 3). Other isolates did not reduce germination compared to the bacteria free control. Isolates 8 and 22 increased D. ischaemum seedling mortality at 14 days after inoculation compared to the bacteria free control. Low germination prevented a proper assessment of the effect of the isolate $4+5$ combination on $D$. ischaemum seedling mortality; these data were removed from the statistical analysis and are not presented. T. officinale was included to aid comparison to other experiments. All isolates except isolate 18 increased T. officinale mortality; a similar response was observed in Experiment 1. This indicates these bacteria are more pathogenic against competitor forbs than D. ischaemum. Based on the results of Experiments 1 and 2, we selected isolates 4 and 5 for further study.

Table 3. Effect of Pantoea spp. isolates on Digitaria ischaemum germination and seedling mortality 14 and 28 days after inoculation in axenic agarose culture. Ten seeds were placed in each Petri dish and each treatment was replicated in three Petri dishes. Taraxacum officinale seeds were also inoculated in separate Petri dishes and included for comparison; mortality was evaluated at 21 days after treatment.

\begin{tabular}{cccccccc}
\hline \multirow{2}{*}{ Bacterial Isolate } & \multicolumn{2}{c}{ Germination (\%) } & \multicolumn{2}{c}{ Seedling Mortality (\%) ${ }^{\dagger}$} \\
\cline { 2 - 8 } & \multicolumn{2}{c}{ D. ischaemum } & \multicolumn{2}{c}{ D. ischaemum } & T. officinale \\
\cline { 2 - 8 } & \multicolumn{2}{c}{ 14 days } & \multicolumn{2}{c}{ 14 days } & 28 days & 21 days \\
\hline 4 & 40 & abc & 0 & b & 29 & 71 & a \\
5 & 53 & ab & 6 & ab & 13 & 86 & a \\
8 & 43 & ab & 18 & a & 43 & 78 & a \\
18 & 43 & ab & 0 & ab & 7 & 33 & b \\
22 & 33 & bc & 19 & a & 25 & 79 & a \\
$4+5$ & 20 & c & - & - & - & 72 & a \\
none & 57 & a & 0 & b & 0 & 17 & b \\
\hline
\end{tabular}

+ Percent mortality is the percentage of emerged seedlings that were determined by visual assessment to be completely dead. $\$$ Means followed by the same letter are not significantly different according to Fisher's Protected LSD test $(\alpha=0.05)$. In columns where no letters are present, the ANOVA determined that the treatment effect was not significant $(\alpha=0.05)$.

3.4. Experiment 3: Effect of Bacterial Isolates alone and in Combination with Curvularia sp. on D. ischaemum, T. repens and P. annua Seedling Mortality

The effect of experimental run was not significant; therefore, the data from two experimental runs were combined. 
Germination of non-inoculated P. annua and T. repens was $93 \%$ and $83 \%$, respectively and was not affected by bacteria or Curvularia treatment (data not presented). D. ischaemum germination was significantly reduced from $71 \%$ to $34 \%$ by Curvularia, but was not affected by bacterial treatment (data not presented).

Bacteria and Curvularia treatment affected T. repens seedling mortality 2 weeks after inoculation (Table 4). Bacterial isolates 4 and 5 alone or in combination with each other caused between 57 and $81 \%$ T. repens mortality compared to 0 and $4 \%$ for RiLB4 and the bacteria free control (Figure 2). When inoculated with Curvularia, seedling mortality was similar across all treatments (64 to $87 \%$ ). Curvularia also increased $D$. ischaemum mortality regardless of bacteria treatment. When averaged across bacterial treatments, Curvularia increased D. ischaemum mortality from $11 \%$ to $73 \%$. In the absence of Curvularia, according to the statistical analysis, isolates 4 and 5 alone or in combination did not affect $D$. ischaemum mortality compared to RiLB4 and the bacteria free control. However, a non-significant trend suggests isolates 4 and 5 inoculated alone increase $D$. ischaemum seedling mortality, but seedlings are not affected by the mixture of isolates 4 and 5 . The bacteria treatments did not affect $P$. annua mortality (data not presented).

Table 4. Effect of Pantoea ananatis isolates 4 and 5 alone and in combination with Curvularia sp. spores outgrowing from surface-sterilized Digitaria ischaemum seeds on Trifolium repens seedling mortality 14 days after inoculation in axenic agarose culture. Ten seeds were placed in each Petri dish and each treatment was replicated in three Petri dishes per experimental run. Combined results of two experimental runs are presented. A Pantoea sp. (RiLB4; Genbank No. KX752781) isolated from Phragmites australis and was included as a standard.

\begin{tabular}{cccccc}
\hline \multirow{2}{*}{ Bacterial Isolate } & \multirow{2}{*}{ Curvularia } & \multicolumn{4}{c}{ Seedling Mortality (\%) } \\
\cline { 3 - 6 } & & T. repens & D. ischaemum $^{+}$ \\
\hline 4 & no & 67 & a $\$$ & 19 & $\mathrm{~b}$ \\
5 & no & 81 & $\mathrm{a}$ & 31 & $\mathrm{~b}$ \\
$4+5$ & no & 57 & $\mathrm{a}$ & 2 & $\mathrm{~b}$ \\
RiLB4 & no & 0 & $\mathrm{~b}$ & 0 & $\mathrm{~b}$ \\
none & no & 4 & $\mathrm{~b}$ & 3 & $\mathrm{~b}$ \\
4 & yes & 73 & $\mathrm{a}$ & 77 & $\mathrm{a}$ \\
5 & yes & 87 & $\mathrm{a}$ & 63 & $\mathrm{a}$ \\
$4+5$ & yes & 87 & $\mathrm{a}$ & 68 & $\mathrm{a}$ \\
RiLB4 & yes & 64 & $\mathrm{a}$ & 77 & $\mathrm{a}$ \\
none & yes & 73 & $\mathrm{a}$ & 83 & $\mathrm{a}$ \\
\hline
\end{tabular}

${ }^{+}$Percent mortality is the percentage of emerged seedlings that were determined by visual assessment to be completely dead. \$ Means followed by the same letter are not significantly different according to Fisher's Protected LSD test $(\alpha=0.05)$.

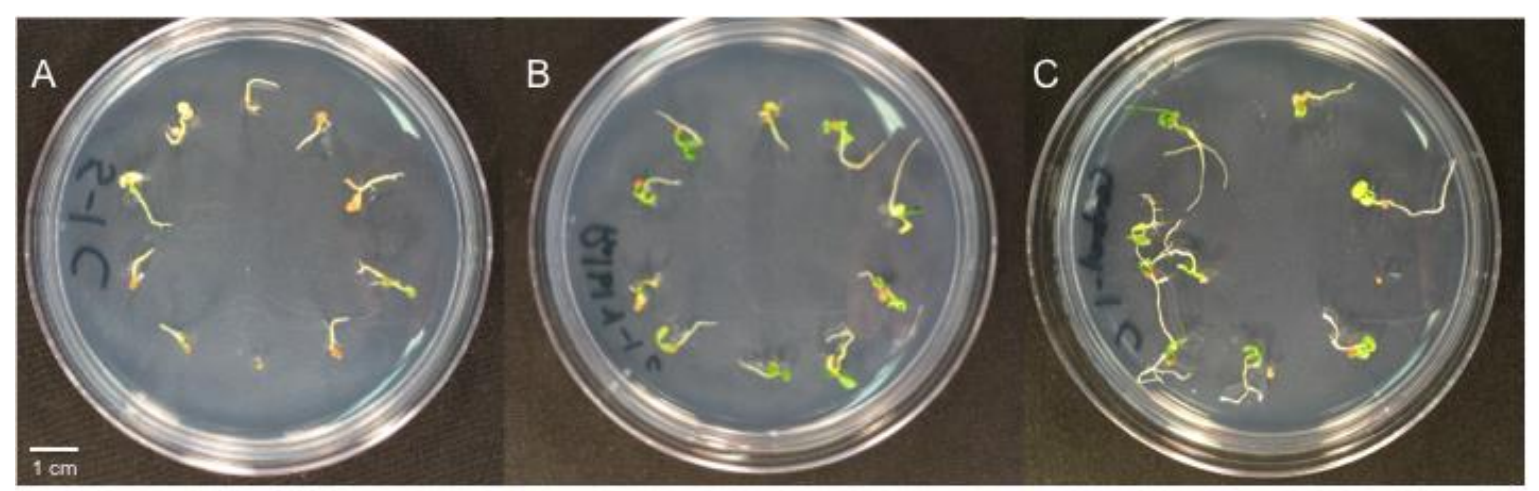

Figure 2. Trifolium repens seedlings 14 days after inoculation with Pantoea sp. Isolate 5 (A), Pantoea sp. Isolate RiLB4 (positive control) (B), and bacteria free control (C). Cotyledons inoculated with isolate 5 are pale and necrotic compared to the positive and bacteria free controls. 
Curvularia increased P. annua mortality from 0 to $6 \%$ when averaged across all bacterial treatments, although this difference may not be biologically significant. Curvularia sp. treatment increased the positive gravitropic response of $P$. annua roots. When averaged across bacterial treatments, $57 \%$ of roots inoculated with Curvularia demonstrated a positive gravitropic response compared to $21 \%$ of roots without Curvularia. Bacteria treatments did not affect root gravitropism (data not presented). Curvularia nor bacteria treatments affected P. annua root length (data not presented).

\subsection{Observation of Bacteria in Seedling Roots}

T. repens and T. officinale root hairs stained with DAB after inoculation with isolate 5 were often malformed and bacteria were observed around root hairs but not usually in the cytoplasm; observations of root hairs treated with isolate 4 were similar except that L-forms of bacteria were occasionally observed in root hair cytoplasm (Figure 1). In every observation $(n>20)$ of DAB stained roots of seeds inoculated with bacteria, large numbers of bacterial rods were present in the rhizosphere, while no bacteria were observed in the rhizosphere of axenic controls. Conclusions from microscopic observations are limited, and the mechanism by which these bacteria kill T. repens and T. officinale should be investigated in more detail.

\section{Discussion}

Our experiments demonstrate that $D$. ischaemum seed contains cultivable bacteria of the Pantoea genus and at least two cultivable fungi in genera Epicoccum and Curvularia. Certain Pantoea ananatis isolates caused more seedling mortality of competitor forbs T. repens and T. officinale than of D. ischaemum in axenic culture, indicating these isolates selectively antagonize forbs. This suggests that $D$. ischaemum seed harbors microbes that may antagonize competitor forbs. However, a natural environment in consortia with other microbes would likely affect the antagonistic characteristic of these microbes.

Pantoea spp. have been isolated as epiphytes from the phyllosphere of other plant species including Oryza sativa and Phragmites australis and can function as growth promoters, plant pathogens, and disease suppressors $[20,39,40]$. P. ananatis is often studied as a plant pathogen, but endophyte isolates can function as growth promoters in pepper and switchgrass (Panicum virgatum L.) [41-44]. Non-pathogenic P. ananatis endophyte isolates have also been found in sugarcane and Miscanthus x giganteus [45,46]. Most of these P. ananatis endophytes were found in root and shoot tissue. However, strains have been isolated from seedlings of surface-sterilized maize kernals [28]. Others investigated the function of three $P$. ananatis endophytes of maize seed and found one isolate was weakly pathogenic and other growth-promotional [29]. Despite several investigations into growth promotion and pathogenicity of host plants, we are not aware of any research demonstrating that $P$. ananatis can kill competitor plants. Research evaluating grass seed-associated bacteria as antagonists of competitor forbs is also limited. Others found that mixtures of certain bacteria associated with Phragmites australis seed increased mortality of T. officinale seedlings in axenic culture to a similar degree as bacteria evaluated in these experiments [20]. Previous research investigating deleterious rhizobacteria (for commercialization) evaluated bacterial strains further if they reduced root length of the target and non-target species by more than $30 \%$ and $10 \%$, respectively, in Petri dish culture [47-49]. We did not measure forb root length in our experiments, but forb: D. ischaemum mortality ratios ranged from 2:1 to 5:1.

This research demonstrates that Pantoea spp. isolated from $D$. ischaemum seed have the capacity to antagonize seedlings of competitor forbs in axenic culture. Pantoea ananatis isolates consistently caused necrosis indicative of membrane leakage in T. repens and T. officinale cotyledons beginning about 7 days after inoculation and progressing until complete death was observed 14 to 21 days after inoculation. In our research, RiLB4 was included as a standard and did not increase mortality of T. repens and T. officinale while several Pantoea spp. isolates from D. ischaemum caused 50 to $80 \%$ mortality of T. repens and T. officinale seedlings. The effect of these isolates on D. ischaemum seedlings was inconsistent, but results indicate that they may increase seedling mortality. However, in some experiments, mortality was reduced when isolates 4 and 5 were combined, thus, this combination demonstrated the greatest 
amount of selectivity for the competitor forbs. It is also possible that removing the $D$. ischaemum seed coat (required to surface sterilize the seed) increased D. ischaemum susceptibility to these bacteria and reduced selectivity for the competitor forbs. Future research should evaluate whether these bacteria are less pathogenic when in consortium with one another or other uncultivable bacteria.

In our experiments, Curvularia functioned primarily as a pathogen of T. repens and D. ischaemum, although with a different combination of bacterial cohorts it may function as a symbiont [10]. Curvularia was much less pathogenic to $P$. annua than $D$. ischaemum and increased the positive gravitropic response of $P$. annua roots. To potentially avert the pathogenic effect against $D$. ischaemum, future research could use more mature seedlings, perhaps allowing plants to develop at least one true leaf before inoculating with this Curvularia sp. isolate to evaluate stress responses similar to [25] and [26]. Extensive observations of seeds inoculated with Curvularia sp. were not conducted in these experiments, but in every observation on multiple dates, segmented hyphae was observed colonizing intercellular spaces of inoculated P. annua and D. ischaemum root cortex tissue, which suggests it has endophytic capabilities (Figure 3).

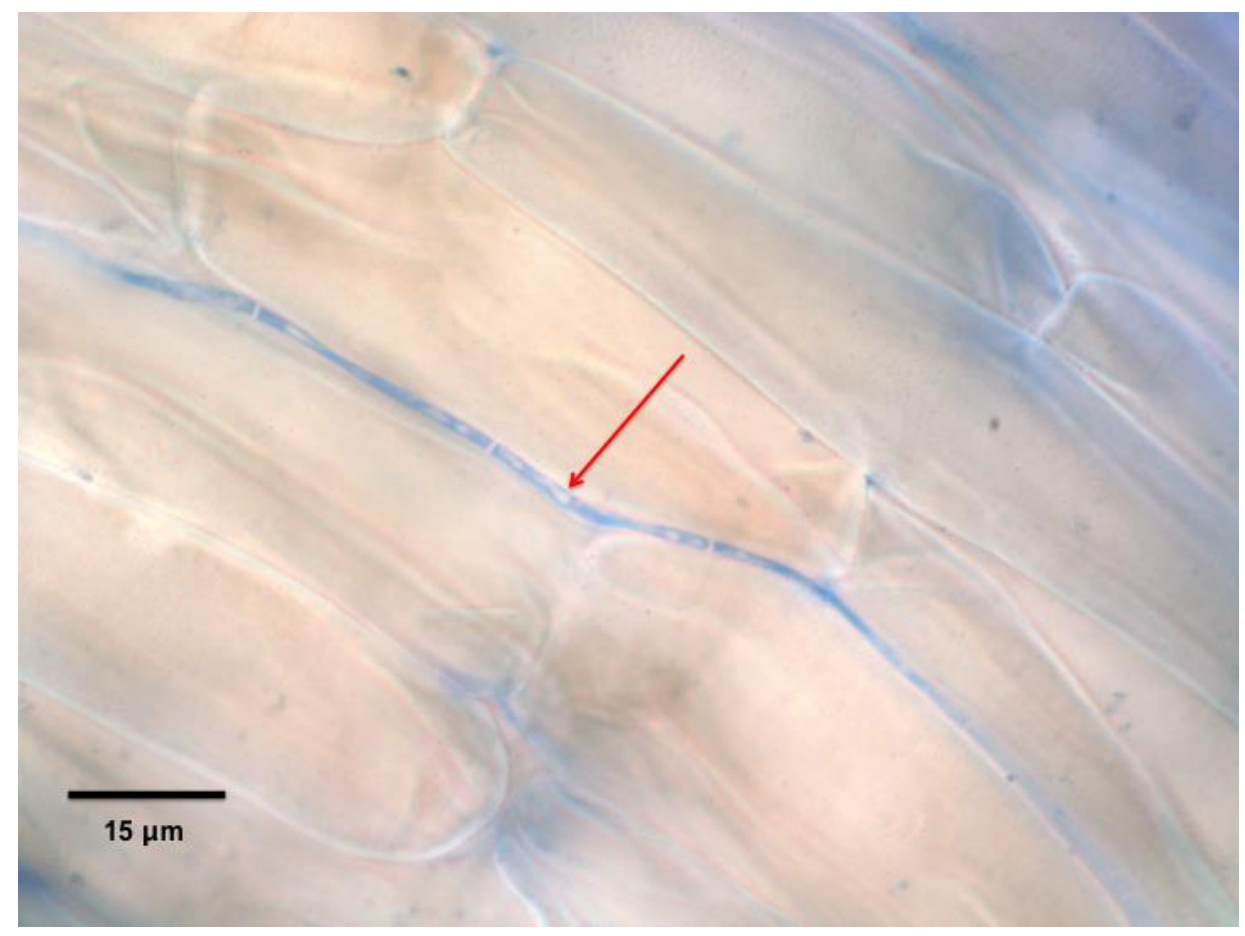

Figure 3. Root cortex cells in the primary Poa annua seedling root 10 days after seeds were inoculated with a Curvularia sp. showing an intercellular fungal hypha (indicated with arrows) stained with aniline blue $(0.1 \%)$.

These experiments demonstrate that Digitaria ischaemum seeds contain bacteria that antagonize competitor species in Petri dish experiments. Pantoea ananatis may provide D. ischaemum a competitive advantage against competitor species. The effect of these isolates alone and in consortia on $D$. ischaemum as compared to competitor forbs should be investigated further. Future research could inoculate these bacteria onto $D$. ischaemum seeds to determine they affect competitiveness.

One limitation of this research is that seeds were collected from only one location for each plant species. Plant microbes likely vary across geographic sites and genotypes. Future research could investigate bacteria associated with P. annua and D. ischaemum seeds collected from different geographic and climatic regions using culture-dependent and culture-independent methods.

The mechanism of selective pathogenicity should also be elucidated. Cyanide production has been implicated as a mechanism by which rhizobacteria suppress plant growth [50], but preliminary experiments suggest that our Pantoea isolates do not produce cyanide. Interestingly, we consistently 
observed cotyledons with a water-soaked appearance prior to necrosis and death. Similar symptoms can be observed in corn plants affected by Pantoea stewartii subsp. stewartii, (the causal agent of Stewart's wilt) as a result of biofilms encased in an exopolycaccharide [51]. However, we did not observe exopolycaccharide blockages in the xylem tissue. The role of Large Pantoea Plasmids in the phenotype and selective forb control we observed should be investigated. These plasmids are common to many Pantoea spp. including $P$. ananatis are thought to be responsible for certain strains to occupy specific ecological niches with various phenotypes such as toxin production and viruluence factors that enable pathogenicity or biocontrol [52-55]. The proteins encoded by Large Pantoea Plasmids may shed light on the bacterial mechanism of action.

Author Contributions: Conceptualization, M.T.E., J.F.W. and S.K.V.; Formal analysis, M.T.E. and K.L.K.; Funding acquisition, M.T.E.; Investigation, M.T.E., K.L.K. and K.H.D.; Methodology, M.T.E., J.F.W., and K.L.K.; Visualization, M.T.E., J.F.W. and S.K.V.; Writing—original draft, M.T.E.; Writing—review \& editing, J.F.W.

Funding: The Rutgers Center for Turfgrass Science and USDA National Institute of Food and Agriculture Hatch project accession number 1013421 through the New Jersey Agricultural Experiment Station, Hatch project NJ12155 funded this research.

Acknowledgments: The authors would like to thank Jeff Borger for providing the P. annua seed, Marshall Bergen and Glen Groben for their technical expertise.

Conflicts of Interest: The authors declare no conflict of interest. The funders had no role in the design of the study; in the collection, analyses, or interpretation of data; in the writing of the manuscript, or in the decision to publish the results.

\section{References}

1. Kim, T.J.; Neal, J.C.; Ditomaso, J.M.; Rossi, F.S. A survey of weed scientists' perceptions on the significance of crabgrasses (Digitaria spp.) in the United States. Weed Technol. 2002, 16, 239-242. [CrossRef]

2. Zhou, B.; Kong, C.H.; Wang, P.; Li, Y.H. Chemical constituents of the essential oils of wild oat and crabgrass and their effects on the growth and allelochemical production of wheat. Weed Biol. Manag. 2013, 13, 62-69. [CrossRef]

3. Zhou, B.; Kong, C.H.; Wang, P.; Li, Y.H. Crabgrass (Digitaria sanguinalis) allelochemicals that interfere with crop growth and the soil microbial community. J. Agric. Food Chem. 2013, 61, 5310-5317. [CrossRef] [PubMed]

4. Chwedorzewska, K.J.; Gielwanowska, I.; Olech, M.; Molina-Montenegro, M.A.; Wódkiewicz, M.; Galera, H. Poa annua L. in the maritime Antarctic: An overview. Polar Rec. 2015, 51, 637-643. [CrossRef]

5. Beard, J.B.; Rieke, P.E.; Turgeon, A.J.; Vargas, J.M. Annual Bluegrass (Poa annua L.) Description, Adaptation, Culture, and Control; Michigan State University: East Lansing, MI, USA, 1978; pp. 1-32.

6. Hardoim, P.R.; van Overbeek, L.S.; van Elsas, J.D. Properties of bacterial endophytes and their proposed role in plant growth. Trends Microbiol. 2008, 16, 463-471. [CrossRef]

7. Truyens, S.; Weyens, N.; Cuypers, A.; Vangronsveld, J. Bacterial seed endophytes: Genera, vertical transmission and interaction with plants. Environ. Microbiol. Rep. 2015, 7, 40-50. [CrossRef]

8. Wilson, D. Endophyte-The evolution of a term, and clarification on its use and definition. Oikos 1995, 73, 274-276. [CrossRef]

9. Compant, S.; Clement, C.; Sessitsch, A. Plant growth-promoting bacteria in the rhizo- and endosphere of plants: Their role, colonization, mechanisms involved and prospects for utilization. Soil Biol. Biochem. 2010, 42, 669-678. [CrossRef]

10. Podolich, O.; Ardanov, P.; Zaets, I.; Pirttila, A.M.; Kozyrovska, N. Reviving of the endophytic bacterial community as a putative mechanism of plant resistance. Plant Soil 2015, 388, 367-377. [CrossRef]

11. Rodriguez, R.J.; White, J.F.; Arnold, A.E.; Redman, R.S. Fungal endophytes: Diversity and functional roles. New Phytol. 2009, 182, 314-330. [CrossRef]

12. Clay, K. Fungal Endophytes of Grasses. Annu. Rev. Ecol. Syst. 1990, 21, 275-297. [CrossRef]

13. Schardl, C.L. Epichloë festucae and related mutualistic symbionts of grasses. Fungal Genet. Biol. 2001, 33, 69-82. [CrossRef]

14. Trognitz, F.; Hackl, E.; Widhalm, S.; Sessitsch, A. The role of plant-microbiome interactions in weed establishment and control. FEMS Microbiol. Ecol. 2016, 92, 1-15. [CrossRef] 
15. Shipunov, A.; Newcombe, G.; Raghavendra, A.K.H.; Anderson, C.L. Hidden diversity of endophytic fungi in an invasive plant. Am. J. Bot. 2008, 95, 1096-1108. [CrossRef]

16. Aschehoug, E.T.; Metlen, K.L.; Callaway, R.M.; Newcombe, G. Fungal endophytes directly increase the competitive effects of an invasive forb. Ecology 2012, 93, 3-8. [CrossRef]

17. Clay, K.; Shearin, Z.R.C.; Bourke, K.A.; Bickford, W.A.; Kowalski, K.P. Diversity of fungal endophytes in non-native Phragmites australis in the Great Lakes. Biol. Invasions 2016, 18, 2703-2716. [CrossRef]

18. Ernst, M.; Mendgen, K.W.; Wirsel, S.G.R. Endophytic fungal mutualists: Seed-borne Stagonospora spp. enhance reed biomass production in axenic microcosms. Mol. Plant-Microbe Interact. 2003, 16, 580-587. [CrossRef]

19. Shearin, Z.R.C.; Filipek, M.; Desai, R.; Bickford, W.A.; Kowalski, K.P.; Clay, K. Fungal endophytes from seeds of invasive, non-native Phragmites australis and their potential role in germination and seedling growth. Plant Soil 2017, 1-12. [CrossRef]

20. White, J.F.; Kingsley, K.I.; Kowalski, K.P.; Irizarry, I.; Micci, A.; Soares, M.A.; Bergen, M.S. Disease protection and allelopathic interactions of seed-transmitted endophytic pseudomonads of invasive reed grass (Phragmites australis). Plant Soil 2018, 422, 195-208. [CrossRef]

21. Anton, A.; Connor, H.E. Floral biology and reproduction in Poa (Poeae: Gramineae). Aust. J. Bot. 1995, 43, 577-599. [CrossRef]

22. Kardol, P.; Cornips, N.J.; van Kempen, M.M.; Bakx-Schotman, J.M.; van der Putten, W. Microbe-mediated plant-soil feedback causes historical contingency effects in plant community assembly. Ecol. Monogr. 2007, 77, 147-162. [CrossRef]

23. Zhou, W.-N.; White, J.F.; Soares, M.A.; Torres, M.S.; Zhou, Z.-P.; Li, H.-Y. Diversity of fungi associated with plants growing in geothermal ecosystems and evaluation of their capacities to enhance thermotolerance of host plants. J. Plant Interact. 2015, 10, 305-314. [CrossRef]

24. Redman, R.S.; Litvintseva, A.; Sheehan, K.B.; Henson, J.M.; Rodriguez, R.J. Fungi from geothermal soils in Yellowstone National Park. Appl. Environ. Microb. 1999, 65, 5193-5197.

25. Redman, R.S.; Sheehan, K.B.; Stout, R.G.; Rodrigues, R.J.; Henson, J.M. Thermotolerance generated by plant/fungal symbiosis. Science 2002, 298, 1581. [CrossRef]

26. Marquez, L.; Redman, R.; Rodrigues, R.; Roossinck, M.J. A virus in a fungus in a plant. Science 2007, 315, 513-516. [CrossRef]

27. Lush, W.M. Biology of Poa annua in a temperate zone golf putting green (Agrostis stolonifera/Poa annua) II. The seed bank. J. Appl. Ecol. 1988, 25, 989-997. [CrossRef]

28. Rijavec, T.; Lapanje, A.; Dermastia, M.; Rupnik, M. Isolation of bacterial endophytes from germinated maize kernels. Can. J. Microbiol. 2007, 53, 802-808. [CrossRef] [PubMed]

29. Sheibani-Tezerji, R.; Naveed, M.; Jehl, M.; Sessitsch, A.; Rattei, T.; Mitter, B. The genomes of closely related Pantoea ananatis maize seed endophytes having different effects on the host plant differ in secretion system genes and mobile genetic elements. Front. Microbiol. 2015, 6, 1-16. [CrossRef]

30. Puente, M.E.; Li, C.Y.; Bashan, Y. Endophytic bacteria in cacti seeds can improve the development of cactus seedlings. Environ. Exp. Bot. 2009, 66, 402-408. [CrossRef]

31. Ringelberg, D.; Foley, K.; Reynolds, C.M. Bacterial endophyte communities of two wheatgrass varieties following propagation in different growing media. Can. J. Microbiol. 2012, 58, 67-80. [CrossRef]

32. Hodgson, S.; de Cates, C.; Hodgson, J.; Morley, N.J.; Sutton, B.C.; Gange, A.C. Vertical transmission of fungal endophytes is widespread in forbs. Ecol. Evol. 2014, 4, 1199-1208. [CrossRef] [PubMed]

33. Liu, Y.; Zuo, S.; Xu, L.; Zou, Y.; Song, W. Study on diversity of endophytic bacterial communities in seeds of hybrid maize and their parental lines. Arch. Microbiol. 2012, 194, 1001-1012. [CrossRef]

34. Videira, S.S.; de Oliveira, D.M.; de Morais, R.F.; Borges, W.L.; Baldani, V.L.D.; Baldani, J.I. Genetic diversity and plant growth promoting traits of diazotrophic bacteria isolated from two Pennisetum purpureum Schum. genotypes grown in the field. Plant Soil 2012, 356, 51-66. [CrossRef]

35. Lane, D.J. 16S/23S rRNA sequencing. In Nucleic Acid Techniques in Bacterial Systematics, 1st ed.; Goodfellow, M., Stackebrandt, E., Eds.; Wiley: New York, NY, USA, 1991; pp. 115-175.

36. White, J.F.; Torres, M.S.; Somu, M.P.; Johnson, H.; Irizarry, I.; Chen, Q.; Zhang, N.; Walsh, E.; Tadych, M.; Bergen, M. Hydrogen peroxide staining to visualize intracellular bacterial infections of seedling root cells. Microsc. Res. Tech. 2017. [CrossRef] 
37. Barnett, H.L.; Hunter, B.B. Illustrated Genera of Imperfect Fungi, 4th ed.; American Phytopathological Society: St. Paul, MN, USA, 1998; Volume 1, p. 240.

38. Verma, S.; Kinglsey, K.; Bergen, M.; English, C.; Elmore, M.; Kharwar, R.; White, J. Bacterial endophytes from rice cut grass (Leersia oryzoides L.) increase growth, promote root gravitropic response, stimulate root hair formation, and protect rice seedlings from disease. Plant Soil 2018, 422, 223-238. [CrossRef]

39. Cottyn, B.; Regalado, E.; Lanoot, B.; DeCleene, M.; Mew, T.W.; Swings, J. Bacterial populations associated with rice seed in the tropical environment. Phytopathology 2001, 91, 282-292. [CrossRef] [PubMed]

40. Walterson, A.M.; Stavrinides, J. Pantoea: Insights into a highly versatile and diverse genus within the Enterobacteriaceae. FEMS Microbiol. Rev. 2015, 39, 968-984. [CrossRef]

41. Coutinho, T.A.; Venter, S.N. Pantoea ananatis: An unconventional plant pathogen. Mol. Plant Pathol. 2009, 10, 325-335. [CrossRef] [PubMed]

42. Gagne-Bourne, F.; Aliferis, K.A.; Seguin, P.; Rani, M.; Samson, R.; Jabaji, S. Isolation and characterization of indigenous endophytic bacteria associated with leaves of switchgrass (Panicum virgatum L.) cultivars. J. Appl. Microbiol. 2013, 114, 836-853. [CrossRef] [PubMed]

43. Hoon, S.K.; Cho, H.-S.; Cheong, H.; Ryu, C.-M.; Kim, J.F.; Park, S.-H. Two bacterial entophytes eliciting both plant growth promotion and plant defense on pepper (Capsicum annuum L.). J. Microbiol. Biotchnol. 2007, 17, 96-103.

44. Kim, S.; Cho, W.K.; Kim, W.; Jee, H.J.; Park, C. Growth promotion of pepper plants by Pantoea ananatis B1-9 and its efficient endophytic colonization capacity in plant tissues. Plant Pathol. J. 2012, 28, 270-281. [CrossRef]

45. Da Silva, J.F.; Barbosa, R.R.; Souza, A.N.; De Motta, O.V.; Teixeira, G.N. Isolation of Pantoea ananatis from sugarcane and characterization of its potential for plant growth promotion. Genet. Mol. Res. 2015, 14, 15301-15311. [CrossRef]

46. Schmidt, C.S.; Mrnka, L.; Frantík, T.; Lovecká, P.; Vosátka, M. Plant growth promotion of Miscanthus $\times$ giganteus by endophytic bacteria and fungi on non-polluted and polluted soils. World J. Microbiol. Biotechnol. 2018, 34, 34-48. [CrossRef]

47. Kennedy, A.C.; Young, F.L.; Elliott, L.F.; Douglas, C.L. Rhizobacteria suppressive to the weed downy brome. Soil Sci. Soc. Am. J. 1991, 55, 722-727. [CrossRef]

48. Kremer, R.J.; Kennedy, A.C. Rhizobacteria as biocontrol agents of weeds. Weed Technol. 1996, 10, 601-609. [CrossRef]

49. Kennedy, A.C. Pseudomonas fluorescens strains selectively suppress annual bluegrass (Poa annua L.). Biol. Control 2016, 103, 210-217. [CrossRef]

50. Kremer, R.J.; Souissi, T. Cyanide production by rhizobacteria and potential for suppression of weed seedling growth. Curr. Microbiol. 2001, 43, 182-186. [CrossRef]

51. Roper, M.C. Pantoea stewartii subsp. stewartii: Lessons learned from a xylem-dwelling pathogen of sweet corn. Mol. Plant Pathol. 2011, 12, 628-637. [CrossRef]

52. De Maayer, P.; Chan, W.-Y.; Blom, J.; Venter, S.N.; Duffy, B.; Smits, T.H.M.; Coutinho, T.A. The large universal Pantoea plasmid LPP-1 plays a major role in biological and ecological diversification. BMC Genom. 2012, 13, 625. [CrossRef]

53. Kamber, T.; Lansdell, T.A.; Stockwell, V.O.; Ishimaru, C.A.; Smits, T.H.M.; Duffy, B. Characterization of the biosynthetic operon for the antibacterial peptide herbicolin in Pantoea vagans biocontrol strain C9-1 and incidence in Pantoea species. Appl. Environ. Microbiol. 2012, 78, 4412-4419. [CrossRef]

54. Weinthal, D.M.; Barash, I.; Panijel, M.; Valinski, L.; Gaba, V.; Manulis-Sasson, S. Distribution and replication of the pathogenicity plasmid pPATH in diverse populations of the gall-forming bacterium Pantoea agglomerans. Appl. Environ. Microbiol. 2007, 73, 7552-7561. [CrossRef] [PubMed]

55. Vivian, A.; Murillo, J.; Jackson, R.W. The roles of plasmids in phytopathogenic bacteria: Mobile arsenals? Microbiology 2001, 147, 763-780. [CrossRef] [PubMed]

(C) 2019 by the authors. Licensee MDPI, Basel, Switzerland. This article is an open access article distributed under the terms and conditions of the Creative Commons Attribution (CC BY) license (http://creativecommons.org/licenses/by/4.0/). 